\title{
PERNIKAHAN DINI DI INDONESIA: FAKTOR DAN PERAN PEMERINTAH (PERSPEKTIF PENEGAKAN DAN PERLINDUNGAN HUKUM BAGI ANAK)
}

\author{
Ana Latifatul Muntamah ${ }^{1}$, Dian Latifiani ${ }^{2}$, Ridwan Arifin ${ }^{3}$
}

\begin{abstract}
Early marriage in Indonesia is one of the problems not only related to marital law (the age limit of marriage), but also related to issues of child protection and human rights. Many factors underlie early marriage, starting from the factors of customs, families, religious views, to the economy. In fact, based on the facts and results of research, early marriage at least provides a social impact, namely the occurrence of divorce, weak family stability, the occurrence of gender discrimination, and parenting to children who are not optimal. This research discusses two important things, namely, first, what is the role of the government in upholding and protecting children's rights in cases of early marriage in Indonesia, and second, what factors influence the enforcement and protection of children's rights in early marriage. This study uses qualitative methods with socio-legal approach by comparing existed cases either through print or online media with relevant laws and regulations. This study confirms that in the case of early marriage, there are at least some children's rights that are violated, namely: (1) the right to education, (2) the right to protection, (3) the right to play and recreation, (4) the right to equality. In the case of early marriage, children are often victims of violence and discrimination. In some cases, early marriage also causes the release of parental responsibility to children.
\end{abstract}

Kata kunci: Pernikahan Dini, Perlindungan Anak, Hak Asasi Manusia, Aspek Hukum

\section{PENDAHULUAN}

Angka pernikahan dini di banyak Negara terus meningkat dari tahun ke tahun dan selalu berhubungan dengan berbagai upaya perlindungan hokum terhadap anak. Pada tahun 2015, ada sekitar 142 juta anak perempuan yang melakukan pernikahan sebelum waktunya (CFR 2015). ${ }^{4}$ Angka tersebut terus meningkat terutama di beberapa Negara seperti Afrika, Asia Barat Daya,
Ethopia, India, dll. Ethiopia misalnya, merupakan negara dengan jumlah pernikahan dini tertinggi di dunia. Tradisi yang kuat, ekonomi, dan agama merupakan alasan yang paling dominan untuk praktik pernikahan di negara ini. Karena membangun rumah tangga dari proses pernikahan dini tersebut, banyak terjadi beberapa permasalahan seperti penurunan kondisi anak perempuan dalam segi psikologis dan emosional, kekerasan

Fakultas Hukum Universitas Negeri Semarang (UNNES), email: anaoppo0@gmail.com

Bagian Hukum Perdata Fakultas Hukum Universitas Negeri Semarang (UNNES), email: dianlatifiani@mail.unnes.ac.id

3 Pusat Bantuan Hukum Fakultas Hukum Universitas Negeri Semarang (UNNES), email: ridwan.arifin@mail.unnes.ac.id

4 Dewi Candraningrum, "Pernikahan Anak: Status Anak Perempuan?”, Jurnal Perempuan, Vol. 21 No. 1, Februari 2016, hlm. iii-v 
dalam rumah tangga (KDRT), dan deklanasi layanan sosial, masalah migrasi, dan kesehatan reproduksi. Kondisi yang hamper serupa juga terjadi di Indonesia, dimana setiap tahunnya, 1,5 juta anak perempuan telah menikah dini, angka tersebut setara dengan gadis yang menikah setiap dua detiknya. Meskipun undang-undang perkawinan yang memberlakukan 18 tahun sebagai usia minimun pernikahan, namun dalam praktiknya pernikahan anak semakin meluas. Secara universal, 720 juta wanita yang hidup dan menikah sebelum usia 18 tahun, yakni kisaran 15 tahun. ${ }^{5}$

Ada persepsi yang kuat dari orang tua mengenai suatu konsep pernikahan dibawah umur oleh anak perempuan. Beberapa hasil penelitian dan survei Agege, dkk (2018) tentang konsep pernikahan dini pun berbedabeda, dimana pernikahan dini dianggap sebagai pernikahan yang kurang dari usia 18 tahun: Sangat setuju sebanyak 63\% dan 30\%, pernikahan dini disebut pernikahan remaja sebesar 53\% sangat setuju dan 37\%, sebagai pelanggaran pada anak perempuan disebutkan bahwa sangat setuju sebesar $46 \%$ dan setuju $33 \%$. Jelaslah bahwa ada lebih banyak ketidaksepakatan oleh responden mengenai persepsi tentang penyebab pernikahan dini. Secara khusus, mayoritas sederhana dari $60 \%$ belum mengakui diskriminasi gender dalam praktik dasar pernikahan dini. Namun, 77\% mengakui bahwa ketidaktahuan terhadap penyebabnya, sehingga dapat juga disimpulkan dari hal tersebut, bahwa ketidaktahuan telah secara tidak sengaja menyebabkan anak-anak perempuan sehingga tidak diberi perhatian yang seharusnya

5 Sophia Chae dan Thoai D. NGO. "The Global State of Evidence on Interventions to Prevent Child Marriage", Girl Center Research Brief, No. 1, October 2017.

6 Emmanuel A. Agege, Ezekiel U. Nwose, dan Stella Odjimogho. "Parental perception of girl-child early marriage amongst the Urhobos in Nigeria", International Journal of Community Medicine and Public Health, Vol. 5 No. 8, Agustus 2018, hlm. 3189, DOI: http://dx.doi.org/10.18203/23946040.ijcmph20183049 mereka dapatkan, sehingga mengarah ke gaya hidup yang tidak berbudaya/bermoral, sehingga hal tersebut yang menyebabkan seorang anak perempuan menjadi hamil sebelum terjadinya pernikahan. ${ }^{6}$

Sedangkan, kasus di Nepal India, dimana sensus yang dilakukan pada tahun 2011 menujukkan bahwa masih 14,9\% anakanak putus sekolah di Nepal dan 27,7\% di distrik Danusha (seperti dikutip dalam MOE, 2013). Dengan cara yang sama, Laporan Flash I dari DOE (2012) menunjukkan bahwa angka putus sekolah dan tingkat retensi untuk anakanak menyelesaikan Pendidikan dasar (kelas 8). Selain itu, dijelaskan bahwa sekitar $27,1 \%$ dari Pendidikan menengah lengkap siswa. ${ }^{7}$

Sementara itu di Indonesia, pernikahan dini sudah menjadi fenomena nasional, budaya menjadi faktor yang berpengaruh besar terhadap pola kehidupan dalam masyarakat, termasuk dalam pernikahan dini. Pernikahan berbagai etnis, memperlihatkan bahwa masalah perkawinan dini perlu sangat diperhatikan. Indonesia menempati peringkat ke-37 dengan jumlah pernikahan di bawah umur tertinggi di dunia, dan ke 2 di Asia Tenggara. Tentu bukan hal yang membanggakan karena ini mempengaruhi kepadatan penduduk, karena berpotensi terhadap kelahiran yang tinggi pula. ${ }^{8}$ Konsep menikah, dianggap sebagai sebuah akad/kesepakatan yang mengakibatkan halalnya hubungan perempuan dengan seorang laki-laki yang sesuai dengan ketentuan syara', ${ }^{9}$ namun dalam kasus pernikahan dini, seringkali kesepatan yang

7 Mahato, Santosh K. "Causes and Consequences of Child Marriage: A Perspective”, International Journal of Scientific \& Engineering Research, Vol. 7 No. 7, Juli 2016, hlm. 698.

8 Nasution, Rosramadhana. Ketertindasan Perempuan Dalam Tradisi Kawin Anom: Subaltern Perempuan pada Suku Banjar dalam Perspektif Poskolonial, Jakarta, Yayasan Pustaka Obor Indonesia, 2016, hlm. 1.

9 Muhammad Nabil Khazim, 2007, Buku Pintar Nikah: Strategi Jitu Menuju Pernikahan Sukses, Samudera, Solo, hlm. 25. 
ada justru bukan terletak pada anak namun pada orangtua si anak.

Permasalahan pernikahan dini menjadi sangat penting untuk diperhatikan, bahkan ada suatu desa di Indonesia yang sangat merespon positif terhadap pernikahan dini ini. Karena mereka beranggapan bahwa pernikahan dini adalah suatu tradisi dari nenek moyang yang harus dilestarikan secara turun menurun. Salah satu Kecamatan yang menjadikan pernikahan usia dini sebagai eksistensi yakni di Kecamatan Seberang Ulu I Kota Palembang. Disana sangat banyak terjadi pernikahan di usia dini, bahkan sudah dijadikan sebagai kebiasaan masyarakat disana. Seolah-olah Undang-Undang yang telah mengaturnya diabaikan begitu saja tanpa menyentuh akal pikiran masyarakat. Kebanyakan yang melakukan pernikahan di usia dini adalah anak yang berusia di bawah 16 tahun, bisa di rata-rata mereka adalah yang berusia 13-15 tahun.

Penelitian Handayani

(2014)

mengungkapkan bahwa angka pernikahan dini sangat tinggi, dikarenakan beberapa penyebab, yang pertama, remaja putri yang berpengetahuan rendah lebih rentan dua 2,3 kali melakukan pernikahan dini dibandingkan dengan yang berpengetahuan tinggi. Yang kedua, remaja putri dengan lingkungan yang negative akan lebih beresiko 2,1 kali melakukan pernikahan dini dibandingkan dengan yang berada pada lingkungan yang positif. Yang ketiga, remaja putri yang berpendidikan rendah akan lebih rentan 5,4 kali melakukan pernikahan dini dibandingkan dengan yang berpendidikan tinggi. Yang keempat, remaja putri yang orang tuanya tidak bekerja akan beresiko 7.4 kali melakukan pernikahan dini dibandingkan dengan remaja putri yang orangtuanya bekerja. Jadi dapat disimpulkan bahwa faktor yang paling beresiko menyebabkan anak melakukan pernikahan dini yakni ketika orang tuanya

10 Eka Yuli Handayani, "Faktor-Faktor Yang Berhubungan Dengan Pernikahan Usia Dini Pada Remaja Putri di Kecamatan Tambusai Utara Kabupaten Rokan Hulu", Jurnal Maternity and Neonatal, Volume 1 No. 5, 2014, hlm. 203 tidak bekerja, otomatis adalah faktor ekonomi. Entah karena keinginan orangtuanya atau keinginan anak, mereka sama-sama tidak ingin direpotkan lagi, karena mereka sadar bahwa orangtuanya tidak mampu lagi untuk bisa menghidupi mereka. Namun, di sisi lain hal ini sangatlah memprihatinkan. Si anak yang masih di bawah umur, dan orang tua yang tidak bisa lagi menanggung anak. ${ }^{10}$

Badan Kependudukan dan Keluarga Berencana Nasional (BKKBN) menegaskan bahwa Indonesia merupakan negara dengan jumlah presentase pernikahan di usia dini yang tinggi di dunia. Hal itu dibuktikan dengan data BKKBN yang mengatakan bahwa, "Perempuan muda di Indonesia dengan usia 10-14 sebanyak 0,2\% atau lebih dari 22.000 (dua puluh dua ribu) sudah menikah (BKKBN). Kepala BKKBN, Surya Chandra Surapaty mengatakan bahwa julah remaja di Indonesia yang sudah memiliki anak cukup sangat tinggi yaitu 48 dari 1000 (seribu) remaja. ${ }^{11}$

Hasil dari penelitian yang dilakukan oleh Plan Indonesia yang bekerjasama dengan Pusat Studi Kependudukan dan Kebijakan (PSKK) UGM tahun 2011 tentang "Praktik Pernikahan Dini di Indonesia" di delapan lokasi di Indonesia yaitu Indramayu, Grobogan, Rembang, Tabanan, Dompu, Sikka, Lembata, dan Timur Tengah Selatan (TTS), memaparkan bahwa rata-rata usia nikah di wilayah tersebut adalah usia 16 tahun. Dampaknya dari pernikahan di bawah umur tersebut beragam, diantaranya terkait dengan kesehatan reproduksi. Hamper di semua wilayah itu, anak perempuan yang menikah dini itu beresiko mengalami kehamilan yang berisiko tinggi. Dampak lainnya yakni pada kesehatan mental, dampak tersebut sangat dirasakan oleh anak perempuan, hal tersebut sangat fatal disebabkan anak perempuan yang menikah di

11 Wisono Mulyadi, Anjar Sri Ciptorukmi Nugraheni, "Akibat Hukum Penetapan Dispensasi Perkawinan Anak di Bawah Umur (Studi Kasus di Pengadilan Agama Pacitan), Privat Law, Vol. V No 2 Juli Desember 2017, hlm. 70. 
usia dini belum bisa menanggung beban yang sangat berat dan bahkan anak perempuan bisa mengalami stress karena memang belum waktunya untuk menanggung beban yang sangat berat tersebut. Hal tersebut sangat terasa sesaat setelah anak perempuan berpisah dengan keluarganya dan bertanggungjawab atas keluarganya sendiri. Hal lainnya yang menjadi dampak buruk pernikahan dini adalah rentannya kekerasan dalam rumah tangga (KDRT). Menurut hasil temuan yang dilakukan oleh Plan, sejumlah $44 \%$ anak perempuan yang kawin dini, mengalami kasus KDRT dalam frekuensi yang tinggi. Dan sisanya $56 \%$ yang tidak nikah dini mengalami KDRT dalam frekuensi yang rendah. Selain itu, nikah dini juga memiliki dampak pada kesehatan siem reproduksi anak perempuan. Anak perempuan yang berumur 10-14 tahun berpotensi lima kali lebih berisiko pada masa kehamilan dan melahirkan, dibanding dengan ibu hamil yang usianya 20-25 tahun. Dapat disimpulkan, bahwa pernikahan dini memposisikan anak perempuan sebagai kelompok yang rentan terkait dengan kesehatan reproduksi dan seksualitasnya. ${ }^{12}$

Hasil dari penelitian yang dilakukan oleh Millennium Development Goal's (MDG's) Indonesia pada tahun 2007 yang dterbitkan oleh (Badan Pengawasan Nasional/Bappenas). Menyebutkan bahwa penelitian monitoring Pendidikan oleh education network for justice di beberapa lokasi di Indonesia di enam kelurahan/desa di Kab. Serdang Badagai (Sumatera Utara), Kab. Pasuruan (Jawa Timur), dan Kota Bogor (Jawa Barat) mendapatkan sekitar 28,10\% yang memberi informasi telah menikah pada usia kurang dari 18 tahun. Mayoritasnya adala wanita yakni sejumlah $76,03 \%$ dan terkonsentrasi pada dua desa di Jawa Timur $(58,31 \%)$. Sesuai dengan data yang didaptkan dari BKKBN yang memaparkan bahwa tingginya pernikahan pada usia kurang dari 16 tahun di Indonesia, yakni sampai $25 \%$ dari banyaknya pernikahan yang dilakukan. Bahkan ada di beberapa wilayah yang presentasinya lebih besar dari itu, yakni Jawa Timur yang mencapai 39,43\%, Jambi mencapai 30,63\%, Kalimantan Selatan sebanyak 35,48\%, Jawa Barat sebanyak 36\%, dan di Jawa Tengah mencapai 27,84. Sama seperti penemuan Komisi Perlindungan Anak Indonesia (KPAI) di Kawasan pintura, pernikahan anak sebanyak 35\%, dan $20 \%$ dilakukan oleh anak berusia 9-11 tahun. Di sisi lain, laporan dari Into A New World: Young Women's Sexual and Reproductive Live yang didukung oleh The William $\mathrm{H}$ Gates Foundation pada 1998 telah mengungkapkan bahwa usia 13-18 tahun merupakan usia pertama kali melahirkan di Indonesia, bahkan mencapai $18 \%$ dan pada tahun 1998 pernikahan usia kurang dari 18 tahun mencapai $49 \%$. Kondisi yang hampir sama yakni berdasarkan hasil penelitian yang dilakukan PKPA tahun 2008 di Kabupaten Nias, pernikahan pada usia 13-18 mencapai 9,4\% dari 218 responden jumlah perempuan yang akan dan sudah menikah. Angkah pernikahan dini bagi anak perempuan 3 kali lebih besar dari jumlah anak laki-laki (Sofyan dkk, 2009). Menurut catatan kantor PA (Pengeadilan Agama) di Kota Malang, angka pernikahan dini yakni pada usia 15 tahun meningkat sebesar $50 \%$ disbanding 2007, hingga bulan September 2008 tercatat 10 pernikahan dini yang usia perempuannya kurang dari 15 tahun. Hasil dari Bada Perencanaan Pembangunan Nasional (Bappenas) menunjukkan bahwa dari jumlah 2 juta pernikahan, sebanyak $34,5 \%$ adalah pernikahan dini. Jawa Timur merupakan daerah yang pernikahan dini tertinggi., bahkan lebih dari angka rata-rata nasional yakni $39 \% .^{13}$

12 Djamilah, Reni Kartikawati. "Dampak Perkawinan Anak di Indonesia", Jurnal Studi Pemuda, Vol. 3, No. 1, Mei 2014, hlm. 2, online pada https://journal.ugm.ac.id/jurnalpemuda/article/view File/32033/19357

13 Sakdiyah, Halimatus dan Kustiawati Ningsih. "Mencegah pernikahan dini untuk membentuk generasi berkualitas (Preventing early-age marriage to establish qualified generation)", Masyarakat, Kebudayaan dan Politik, Vol. 26, No.1, 2013, hlm.

4 IPernikahan Dini Di Indonesia.. 
Data yang terdapat di KUA (Kantor Urusan Agama) pada suatu kecamatan, terdapat jumlah perkawinan pada 2013 sebanyak 535 pasang. Jumlah perempuan yang melakukan pernikahan pernikahan usia kurang dari 20 tahun adalah sebanyak 188 orang (35\%), hampir sama pada tahun 2012 bahwa perempuan yang melakukan penikahan dini yakni sebanyak 199 orang (38\%). Survey awal yang dilaksanakan oleh 30 perempuan yang menikah dini yakni kurang dari 20 tahun di kecamatan tersebut, diperoleh informasi bahwa 1 diantaranya sudah bercerai, 5 orang mengalami persalinan lama, 2 orang melahirkan bayi BBLR, 1 orang mengalami abortus, 1 orang mengalami pendarahan, dan 2 bayi meninggal saat dilahirkan. ${ }^{14}$

Kasus yang pernah mencuat terkait pernikahan dini, kasus perkawinan Syech Puji dan Luthfiana Ulfa seperti menampar keberadaan pembuat hukum dan seluruh aparat hukum di Indonesia. Kasus ini bukanlah kasus yang pertama kalinya. Kasus ini merupakan cerminan dari ribuan kasus yang serupa. Dalam praktiknya, perkawinan dini di Indonesia seperti layaknya hukum yang "tidak bergigi" karena sebegitu banyaknya pelanggaran yang terjadi atas hukum yang ada dan tanpa ditindak lanjuti secara hukum. Pada jelas, pada UndangUndang No. 1 Tahun 1974 tentang Perkawinan telah menyatakan mengenai batas umur perkawinan, maka jika tidak menaati sesuai dengan undang-undang tersebut maka itu merupakan pelanggaran terhadap hak anak. ${ }^{15}$ Menurut data yang tercatat di United Nations Development Economic dan Social Affairs (UNDESA,

36, online pada http://journal.unair.ac.id/downloadfullpapers-mkp9b9d8e2432full.pdf

14 Eka Yuli Handayani, 2014, Op.Cit, 201

15 Ridha Ichwanty Sabir, Mustaring, "Perspektif Masyarakat Tentang Perkawinan di Bawah Umur di Desa Ara Kecamatan Bonto Bahari Kabupaten Bulukumba", Jurnal Tomalebbi, Vol. 1 No.2, September 2014, hlm. 86, online pada https://ojs.unm.ac.id/tomalebbi/article/view/1656/6 98

16 Hasan Bastomi, “Tinjauan Batas Umur Perkawinan Menurut Hukum Islam dan Hukum Perkawinan
2010), Indonesia adalah negara dengan jumlah tertinggi pernikahan dini ke 37 pada tahun 2007. Untuk tingkat ASEAN, Indonesia adalah negara ke 2 tertinggi setelah Kamboja. ${ }^{16}$ Dengan cara meningkatkan kepekaan, dan mendidik anak perempuan akan bisa mengurangi konsekuensi buruk pernikahan dini di masa depan. ${ }^{17}$

\section{METODE}

Penelitian ini menggunakan metode deskriptif kualitatif, dengan pendekatan yuridis normatif dimana penulis melakukan analisa terhadap kasus-kasus yang pernah terjadi di Indonesia berkaitan dengan pernikahan dini dengan berbagai peraturan perundang-undangan terkait dalam perspektif perlindungan hak anak. Data-data yang didapat oleh penulis berasal dari berbagai sumber baik media cetak maupun online, dan data-data hasil penelitian sebelumnya. Kualitifikasi penelitian ini digunakan hanya sebatas mengecek pendapat pakar dan pendapat beberapa kelompok masyarakat berkaitan dengan pernikahan dini. Data-data yang menunjukkan daerah dan lokasi tertentu, penulis dapatkan dari hasil-hasil penelitian yang pernah ada sebelumnya.

\section{HASIL DAN PEMBAHASAN}

\section{Perkawinan dalam Dimensi Aturan Hukum}

Maraknya perkawinan usia dini atau perkawinan di bawah umur sangat sering terjadi di Indonesia, dan sebagai pedoman bagi masyarakat untuk masalah perkawinan, pemerintah telah secara jelas mencantumkannya dalam Undang-Undang Perkawinan No. 1 Tahun 1974 tentang

Indinesia", Yudisia Jurnal Pemikiran Hukum dan Hukum Islam, Vol. 7, No. 2, Desember 2016, hlm. 355-356, online pada http://journal.stainkudus.ac.id/index.php/Yudisia/ar ticle/view/2160/1788.

17 Erwinsyah, Argyo Demartoto, Supriyadi Supriyadi. "Early Marriage in Jebres Sub District of Surakarta City", International Journal of Multicultural and Multireligious Understanding (IJMMU), Vol. 5 No. 2, April, 2018, hlm. 336, DOI: http://dx.doi.org/10.18415/ijmmu.v5i2.396 
Perkawinan. Isi dari undang-undang tersebut, telah jelas bahwa batas usia pernikahan bagi pria dan wanita yang pantas atau sudah memasuki usia perkawinan. Hal ini dinyatakan bahwa: "Perkawinan diizinkan jika pria sudah berusia 19 tahun dan wanita 16 tahun" (Adiputra dkk, 1989: 11). Apabila syarat tidak terpenuhi, maka pernikahan tersebut dapat dicegah atau dibatalkan pelaksanaannya. ${ }^{18}$ Secara logis, dapat dikatakan bahwa patokan usia menikah dalam undang-undang itu, tergolong sangat muda. Batas usia demikian sangat tidak menjamin tujuan dari kebahagiaan lahir dan bathin. Wanita muda sangat berpotensi mengalami perpecahan dalam rumah tangga, dan dalam dunia kedokteran dapat menyebabkan penyakin kandungan yang berkaitan dengan ginekologis. ${ }^{19}$

Secara resmi dunia menolak perilaku kekerasan dan diskriminatif bagi anak, bahkan tanpa disadari, tetap saja terjadi hal itu melalui perkawinan anak. Realitas yang dapat dilihat yakni, anak perempuan yang berusia 16 tahun, menikah dengan laki-laki dewasa, bahkan sampai ada laki-laki yang sudah lanjut usia, sehingga tidak pantas disebut suami melainkan kakek. ${ }^{20}$

Secara hukum perkawinan, anak dilegitimasikan oleh Undang-Undang No. 1 Tahun 1974 tentang Perkawinan. Di dalam undang-undang tersebut dinyatakan bahwa anak perempuan boleh menikah saat berusia 16 tahyn, seperti yang tertera pada pasal 7 (1), "Perkawinan hanya diizinkan jika pihak pria sudah mencapai 19 (Sembilan belas) tahun, dan pihak wanita sudah mencapai 16 (enam belas) tahun." Dan pada pasal 26 UU R.I No. 23 Tahun 2002 tentang Perlindungan Anak, menyatakan bahwa orang tua wajib melindungi anaknya dari pernikahan dini.

18 Anggreni Atmei Lubis, "Latar Belakang Wanita Melakukan Perkawinan Usia Dini”, Jurnal Ilmu Pemerintahan dan Sosial Politik, Vol. 4 No.2, 2016, hlm. 151-152, online pada http://ojs.uma.ac.id/index.php/jppuma/article/view/ 453/884.

19 Nommy Horas Thombang Siahaan, Hukum Lingkungan dan Ekologi Pembangunan, Jakarta, Erlangga, 2004, hlm. 43.
Namun, sebagaimana yang tertera pada UU Perkawinan, UU tersebut dengan adanya sanksi pidana sehingga sepertia tiada artinya dalam melindungi anak dari ancaman pernikahan dini. Sehingga apa arti sebuah undang-undang tanpa ada sebuah pidana di dalamnya. Terlalu lalainya pengawasan penegakan hukum di Indonesia sehingga membuat siapa pun memilik celah, termasuk orangtua kelompok/ komunitas tertentu untuk memalsukan dokumen kependudukan, apparat pemerintah, terutama menyangkut usia, agar pernikahan bisa diberlangsungkan. Tidak heran lagi jika kita sering menjumpai anak perempuan yang menikah/dinikahkan pada usia kurang dari 16 tahun. ${ }^{21}$

Di dalam Undang-Undang No. 35 Tahun 2004 menarasikan Perubahan atas Undang-Undang No. 23 Tahun 2002 yakni mengenai Perlindungan Anak, yang dimaksudkan atau merupakan anak yakni seseorang yang belum 18 (delapan belas) tahun, termasuk anak yang masih berada di dalam kandungan ibunya. Anak mempunyai hak yang harus dilindungi, dijamin, dan dipenuhi oleh orang tuanya, masyarakat, keluarga, pemerintah, dan negara. Pada Konvensi Hak Anak PBB tahun 1989, hak anak yakni: 1) hak untuk bermain; 2) hak untuk mendapatkan Pendidikan; 3) hak untuk mendapatkan perlindungan; 4) hak untuk mendapatkan nama (identitas); 5) hak untuk mendapatkan status kebangsaan; 6) hak untuk mendapatkan makanan; 7) hak untuk mendapatkan akses kesehatan; 8) hak untuk mendapatkan rekreasi; 9) hak untuk mendapatkan kesamaan; 10) hak untuk memiliki peran dalam pembangunan. ${ }^{22}$

Suatu hubungan pernikahan dibutuhkan persiapan fisik, psikis, ekonomi, social, kecerdasan (intelektual), budaya, dan

20 Grijns, Mies Hoko Horii, Sulistyowati Irianto, Pinky Saptandari, Taufiqurrohim, Unsiyah Siti Marhamah, Meike Lusye Karolus, Shinta Candra Dwi, Partini, Sita Thamar Van Bemmelen. Menikah Muda di Indonesia: Suara, Hukum, dan Praktik. Jakarta, Yayasan Pustaka Obor Indonesia, 2018, hlm. 75 .

21 Djamilah, Reni Kartikawati, 2014, Op.Cit., hlm. 2

22 Dewi Candraningrum, 2016, Op.Cit., hlm. v 
spiritual. Suatu pernikahan di usia dini tidak bisa memenuhi syarat-syarat yang diatu di dalam pasal 6 yaitu kemauan bebas dari calon mempelai karena belum dewasa. Dan melakukan perkawinan dini yakni sebelum berumur 18 tahun adalah suatu pelanggaran terhadap Undang-Undang No. 35 Tahun 2014 tentang Perlindungan Anak, yang merupakan aturan yang lebih lanjut dari Pasal 28B (2) UUD 1945. Karenanya, umur 16 tahun, dalam Pasal 7 (1) UU Perkawinan telah mengakibatkan ketidakpastian hukum dan melanggar hak-hak anak yang telah dijamin dalam Pasal 1 (3), Pasal 28B (2), dan juga Pasal 28C (1) UUD 1945. Agar usia 16 tahun tidak dimaknai usia menikah dalam Pasal 7 UU Perkawinan adalah secara konstitusional jika dimaknai usia 18 tahun yang beralasan menurut hukum. ${ }^{23}$

\section{Faktor-Faktor Penyebab Pernikahan Dini}

Banyak faktor yang menyebabkan masyarakat menikahkan anaknya di bawah usia. Yang pertama, Faktor Ekonomi, dimana orang tuanya yang sudah tidak mampu untuk membiayai anaknya tersebut karena mereka memiliki lebih dari 5 anak misalnya, lalu mereka berkeputusan untuk bisa menikahkan anaknya dengan orang yang dianggap lebih mampu. Hal ini juga yang menyebabkan tingkat Pendidikan wanita rendah, karena lebih memilih menikah daripada melanjutkan Pendidikan, karena kalaupun mereka ingin bersekolah, orang tuanya tidak memiliki biaya yang cukup untuk menyekolahkannya. Yang kedua, Faktor pendidikan yang rendah adalah yang sangat mempengaruhi pola pemikiran suatu masyarakat, baik dari pendidikan orang tua maupun si anak sendiri. Suatu masyarakat yang memiliki pendidikan yang tinggi pasti akan berpikir dua kali untuk menikah dan menganggap bahwa pernikahan adalah hal

23 Mohd Din, Mujibussalim, dan Eli Dani Isma. "Kebijakan Kriminal dalam Penanggulangan Perkawinan di Bawah Umur", Dusturiyah: Jurnal Hukum Islam, Perundang-undangan dan Pranata Sosial, Vol VII. No.1.Januari-Juni 2017, hlm. 1-19, online di http://jurnal.arraniry.ac.id/index.php/dustur/article/view/2337/16 93 yang kesekian. Berbeda dengan masyarakat yang pendidikannya masih rendah, mereka pasti akan mengutamakan pernikahan karena hanya dengan cara tersebut mereka dapat mengisi kekosongan hari-hari anak-anak mereka dan untuk dapat memenuhi kebutuhan hidup mereka. Tingkat Pendidikan mempengaruhi tingkat kematangan kepribadian seseorang, dengan Pendidikan mereka akan lebih menyaring dan menerima suatu perubahan yang baik, dan merespon lingkungan yang dapat mempengaruhi kemampuan berpikir mereka. Yang ketiga, Faktor Keinginan sendiri. Faktor ini yang sangat sulit untuk dihindari, karena pria dan wanita berpikiran bahwa mereka saling mencintai bahkan tanpa memandang usia mereka, tanpa memandang masalah apa yang nanti akan dihadapi dan apakah mereka mampu untuk memecahkan suatu masalah. Apabila suatu masalah tidak dapat dipecahkan, suatu pernikahan akan terancam bercerai dengan alasan bahwa pikiran mereka sudah tidak seirama lagi. Itulah seharusnya yang menjadi permasalahan dan pertimbangan apabila ingin menikah di usia muda. Yang keempat adalah faktor pergaulan bebas. Kurangnya bimbingan dan perhatian dari orang tua, anak akan mencari jalan supaya mereka bisa merasa bahagia, yaitu dengan bergaul dengan orang-orang yang tidak dilihat terlebih dahulu kelakuannya (bebas). Hal yang sangat sering terjadi yakni hamil duluan di luar ikatan pernikahan. Sehingga karena hal tersebut, mau tidak mau orang tua akan memberi izin kepada anaknya yang masih di bawah umur untuk menikah. ${ }^{24}$

Yang kelima adalah dari Faktor Adat istiadat Menurut adat-istiadat pernikahan sering terjadi karena sejak kecil anak telah dijodohkan oleh kedua orang tuanya. Bahwa pernikahan anakanak untuk segera merealisir

24 Munawwaroh, Siti. "Studi Terhadap Pernikahan Usia Dini di Kecamatan Seberang Ulu I Kota Palembang Ditinjau dari Hukum Islam', Intelektualita, Volume 5, Nomor 1, Juni 2016, hlm. 38, online pada http://jurnal.radenfatah.ac.id/index.php/intelektuali ta/article/view/723/648 
ikatan hubungan kekeluargaan antara kerabat mempelai laki-laki dan kerabat mempelai perempuan yang memang telah lama mereka inginkan bersama, semuanya supaya hubungan kekeluargaan mereka tidak putus (Wigyodipuro, 1967: 133). Selain itu adanya kekhawatiran orang tua terhadap anak perempuannya yang sudah menginjak remaja, sehingga orang tua segera mensarikan jodoh untuk anaknya. Orang tua yang bertempat tinggal di pedesaan pada umumnya ingin cepat-cepat menikahkan anak gadisnya karena takut akan menjadi perawan tua. (BKKBN, 1993: 9). ${ }^{25}$

Kemudian lebih jauh, yang merupakan penyebab dari pernikahan dini yakni karena adanya Media Massa. Gencarnya ekspose seks di media massa mengakibatkan remaja modern kian permisif terhadap seks. ${ }^{26}$ Ada banyak faktor yang mengakibatkan suatu perkawinan dini menjadi marak, termasuk keterlibatan, keabsahan orang tua, dan kekuatan sosial. Pernikahan dini rawan terjadi pada gadis-gadis miskin yang tidak bisa mengenyam pendidikan maupun yang putus sekolah, dan kurangnya informasi mengenai dampak suatu pernikahan dini dikarenakan tinggal di suatu pedesaan. Itulah faktor yang sangat mempengaruhi suatu prakti pernikahan dini. $^{27}$

Perkawinan dini, bagi perempuan akan mengakibatkan banyak risiko, dari aspek biologis seperti (kerusakan organ-organ reproduksi, hamil muda, dan aspek psikologis seperti ketidaksanggupan menjalankan fungsi-fungsi reproduksi dengan baik. Kehidupan rumah tangga menuntuk

25 Beteq Sardi, "Faktor-Faktor Pendorong Pernikahan Dini dan Dampaknya di Desa Mahak Baru Kecamatan Sungai Boh Kabupaten Malinau, eJournal Sosiatri-Sosiologi, Volume 4, Nomor 3, 2016, online pada http://ejournal.sos.fisipunmul.ac.id/site/wpcontent/uploads/2016/08/Jurnal\%20Online $\% 20 \% 2$ 808-29-16-07-11-46\%29.pdf, hlm. 199

26 Agustian, Hesti. "Gambaran Kehidupan Pasangan yang Menikah di Usia Muda di Kabupaten Dharmasraya", Spektrum PLS, Vol. I, No.1, April 2013, hlm. 207, online pada http://ejournal.unp.ac.id/index.php/pnfi/article/vie wFile/1516/pdf tanggungjawab yang besar bagi perempuan maupun laki-laki. ${ }^{28}$

Akibat lainnya yakni, hilangnya hak seorang anak. Lalu, hilangnya hak kesehatan pada anak, persoalan psikologis seperti cemas bahkan depresi. Dan di dalam masyarakat, orang yang menikah dini akan berisiko mengalami kemiskinan yang berkelanjutan.

\section{Peran Pemerintah Daerah terhadap Pernikahan Dini}

Pemerintah Daerah/desa wajib berperan guna menangani maraknya fenomena pernikahan di bawah umur. Dan yang paling berpengaruh yakni peran pemerintah itu sendiri, guna mengatur perikehidupan masyarakatnya agar terarah dengan baik, yakni dengan berbagai macam tahap:

1. Tahap Pendekatan Personal

Tahap yang pertama bisa dilakukan oleh pihak pemerintah untuk menangani maraknya pernikahan dini yakni dengan pendekatan personal dengan cara menasihati. Tahap ini dilakukan oleh Pegawai Pencatat Pernikahan, pada saat ada masyarakat yang mendaftar pernikahan, tetapi dalam persyaratan tersebut yang tidak sesuai dengan UU Perkawinan di Indonesia.

2. Tahap Pendataan

Pada tahap ini, pendataan tersebut dilakukan pada pemerintahan kepala desa. Pemerintah banyak menemukan suatu pernikahan dini. Namun, pemerintah tidak bertanggungjawab dengan adanya peristiwa pernikahan tersebut.

3. Tahap Sosialisasi

27 Simin Montazeri, Maryam Gharacheh, Nooredin Mohammadi, Javad Alaghband Rad, and Hassan Eftekhar Ardabili, "Determinants of Early Marriage from Married Girls' Perspectives in Iranian Setting: A Qualitative Study," Journal of Environmental and Public Health, Vol. 2016, ID 8615929, hlm 18. https://doi.org/10.1155/2016/8615929

28 Sulistyowati Irianto, Perempuan dan Hukum: Menuju Hukum yang Berperspektif Kesetaraan dan Keadilan: 22 Tahun Konvensi CEDAW di Indonesia, Jakarta, Yayasan Obor Indonesia, 2006, hlm. 57.

8| Pernikahan Dini Di Indonesia... 
Mengasi pernikahan dini yakni dengan cara sosialisasi ke masyarakat yakni melalui suatu kegiatan kemasyarakatan misalnya peringatan maulid nabi, gotong royong, posyandu dan lain-lain, pada saat sambutan, kepala desa dengan memberi motivasi kepada orang tua untuk melanjutkan kepada para anak-anak agar melanjutkan Pendidikan ke jenjang yang lebih tinggi, minimal lulusan SMA/MA, dengan begitu anak-anak yang berniat melakukan pernikahan sudah cukup umur dan sesuai dengan ketentuan di dalam UU Perkawinan, sehing terbebas dari tindak pelanggaran atas undang-undang.

4. Ditanggungkan Surat Nikah

Surat nikah yang dipersulit atau dengan proses pembuatan yang sangat rumit, namun masi saja masyarakat tidak memperdulikan hal tersebut. Dengan cara agar masyarakat yang berniat melakukan pernikahan dini agar diberikan efek jera. Karena, jika fenomena ini terus berlanjut, maka tidak hanya memerlukan biasya yang kecil.

5. Perketat Undang-Undang Perkawinan Masyarakat akan merasa takut pabila ingin melangsungkan pernikahan di bawah umur, dikarenakan pemerintah daerah, pemerintah desa maupun Kantor Urusan Agama (KUA) sudah mulai memperketat aturan-aturan mengenai pernikahan. Hal ini dilakukan agar dapat meminimalisir fenomena pernikahan dini. $^{29}$

\section{PENUTUP}

Dapat disimpulkan bahwa tingkat pernikahan dini di Indonesia sangatlah tinggi, itu karena didukung oleh keadaan lingkungan yang salah dan bimbingan atau pengetahuan dari orang orang tua juga salah. Oleh sebab itu perlulan suatu bimbingan yang memadai agar mencegah terjadinya suatu pernikahan dini. Karena banyak dampak negative dibanding dampak positif dari pernikahan dini.

29 Martyan Mita Rumekti dan V. Indah Sri Pinasti, "Peran Pemerintah Derah (Desa) dalam Menangani Maraknya Fenomena Pernikahan Dini di Desa Plosokerep Kabupaten Indramayu, E-Societas:
Dibuktikan bahwa jumlah perceraian dan kasus kekerasan dalam rumah tangga (KDRT) yang meningkat. Anak perempuan adalah yang paling dirugikan dalam pernikahan dini, karena mereka cenderung di nikahkan dengan laki-laki yang sudah dewasa. Banyak hal yang harus ditanggung oleh anak perempuan, itu mengakibatkan kondisi psikologisnya bahkan akan terganggu. Lalu, pernikahan dini, mengakibatkan kenaikan jumlah kelahiran penduduk di Indonesia. Dan meningkatnya jumlah pengangguran di Indonesia. Itu tentu bukan hal yang mudah bagi pemerintah Indonesia, karena pengangguran sampai saat ini pun belum juga terselesaikan. Peran pemerintah sangat diperlukan untuk lebih mempertegas peraturan atau undang-undang perkawinan di Indonesia. Bahkan, undangundang perkawinan di Indonesia seakan-akan tidak memiliki bobot, sehingga seakan-akan diabaikan oleh masyarakat di Indonesia. Lalu, undang-undang perkawinan seakan-akan tidak memiliki makna lagi. Pengetahuan yang kurang merupakan faktor penyebab maraknya pernikahan dini, terutama di daerah pedesaan. Daerah pedesaan cenderung jauh dari akses informasi, sehingga sangatlah diperlukan untuk sosialisasi untuk mencegah terjadinya pernikahan dini.

\section{$-000-$}

\section{DAFTAR PUSTAKA}

Agege, Emmanuel A., Ezekiel U. Nwose, dan Stella Odjimogho. 2018. "Parental perception of girl-child early marriage amongst the Urhobos in Nigeria", International Journal of Community Medicine and Public Health, Vol. 5 No. 8, Agustus, hlm. 3189-3190, DOI: http://dx.doi.org/10.18203/23946040.ijcmph20183049

Jurnal Pendidikan Sosiologi, Vol. 5 No. 6, Oktober 2016, hlm. 11-12. 
Agustian, Hesti. 2013. "Gambaran Kehidupan Pasangan yang Menikah di Usia Muda di Kabupaten Dharmasraya", Spektrum PLS, Vol. I, No.1, April, hlm. 205-217, online pada http://ejournal.unp.ac.id/index.php/pnfi/ article/viewFile/1516/pdf

Bastomi, Hasan. 2016. “Tinjauan Batas Umur Perkawinan Menurut Hukum Islam dan Hukum Perkawinan Indinesia", Yudisia Jurnal Pemikiran Hukum dan Hukum Islam, Vol. 7, No. 2, Desember, hlm. 354-384, online pada http://journal.stainkudus.ac.id/index.ph $\mathrm{p} /$ Yudisia/article/view/2160/1788.

Candraningrum, Dewi. 2016. "Pernikahan Anak: Status Anak Perempuan?", Jurnal Perempuan, Vol. 21 No. 1, Februari 2016, hlm. iii-v.

Chae, Sophia dan Thoai D. NGO. 2017. "The Global State of Evidence on Interventions to Prevent Child Marriage", Girl Center Research Brief, No. 1, October 2017.

Din, Mohd, Mujibussalim, dan Eli Dani Isma. 2017. "Kebijakan Kriminal dalam Penanggulangan Perkawinan di Bawah Umur", Dusturiyah: Jurnal Hukum Islam, Perundang-undangan dan Pranata Sosial, Vol VII. No.1, JanuariJuni, hlm. 1-19, online di http://jurnal.ar-

raniry.ac.id/index.php/dustur/article/vie w/2337/1693

Djamilah, Reni Kartikawati. 2014. "Dampak Perkawinan Anak di Indonesia", Jurnal Studi Pemuda, Vol. 3, No. 1, Mei, hlm. 1-16, online pada https://journal.ugm.ac.id/jurnalpemuda/ article/viewFile/32033/19357

Erwinsyah, Argyo Demartoto, Supriyadi Supriyadi. 2018. "Early Marriage in Jebres Sub District of Surakarta City", International Journal of Multicultural and Multireligious Understanding (IJMMU), Vol. 5 No. 2, April, hlm. 336344 , DOI: http://dx.doi.org/10.18415/ijmmu.v5i2. 396 $\begin{array}{ccc}\text { Grijns, Mies } & \text { Hoko Horii, } & \text { Sulistyowati } \\ \text { Irianto, } & \text { Pinky } & \text { Saptandari, }\end{array}$ Taufiqurrohim, Unsiyah Siti Marhamah, Meike Lusye Karolus, Shinta Candra Dwi, Partini, Sita Thamar Van Bemmelen. 2018. Menikah Muda di Indonesia: Suara, Hukum, dan Praktik. Jakarta: Yayasan Pustaka Obor Indonesia.

Handayani, Eka Yuli. 2014. "Faktor-Faktor Yang Berhubungan Dengan Pernikahan Usia Dini Pada Remaja Putri di Kecamatan Tambusai Utara Kabupaten Rokan Hulu", Jurnal Maternity and Neonatal, Volume 1 No. 5, hlm. 200206.

Irianto, Sulistyowati. 2006. Perempuan dan Hukum: Menuju Hukum yang Berperspektif Kesetaraan dan Keadilan: 22 Tahun Konvensi CEDAW di Indonesia. Jakarta: Yayasan Obor Indonesia.

Khazim, Muhammad Nabil. 2007. Buku Pintar Nikah: Strategi Jitu Menuju Pernikahan Sukses. Solo: Samudera.

Lubis, Anggreni Atmei. 2016. "Latar Belakang Wanita Melakukan Perkawinan Usia Dini”, Jurnal Ilmu Pemerintahan dan Sosial Politik, Vol. 4 No.2, hlm. 150-160, online pada http://ojs.uma.ac.id/index.php/jppuma/a rticle/view/453/884.

Mahato, Santosh K. 2016. "Causes and Consequences of Child Marriage: A Perspective", International Journal of Scientific \& Engineering Research, Vol. 7 No. 7, 2016, hlm. 698-702.

Montazeri, Simin, Maryam Gharacheh, Nooredin Mohammadi, Javad Alaghband Rad, and Hassan Eftekhar Ardabili. 2016. "Determinants of Early Marriage from Married Girls' Perspectives in Iranian Setting: A Qualitative Study," Journal of Environmental and Public Health, Vol. 2016, ID 8615929, hlm 1-8. https://doi.org/10.1155/2016/8615929

Munawwaroh, Siti. 2016. "Studi Terhadap Pernikahan Usia Dini di Kecamatan 
Seberang Ulu I Kota Palembang Ditinjau dari Hukum Islam', Intelektualita, Volume 5, Nomor 1, Juni, hlm. 35-44, online pada http://jurnal.radenfatah.ac.id/index.php/ intelektualita/article/view/723/648

Nasution, Rosramadhana. 2016. Ketertindasan Perempuan Dalam Tradisi Kawin Anom: Subaltern Perempuan pada Suku Banjar dalam Perspektif Poskolonial. Jakarta: Yayasan Pustaka Obor Indonesia.

Rumekti, Martyan Mita dan V. Indah Sri Pinasti. 2016. "Peran Pemerintah Derah (Desa) dalam Menangani Maraknya Fenomena Pernikahan Dini di Desa Plosokerep Kabupaten Indramayu, ESocietas: Jurnal Pendidikan Sosiologi, Vol. 5 No. 6, Oktober, hlm. 1-16.

Sabir, Ridha Ichwanty, Mustaring. 2014. "Perspektif Masyarakat Tentang Perkawinan di Bawah Umur di Desa Ara Kecamatan Bonto Bahari Kabupaten Bulukumba", Jurnal Tomalebbi, Vol. 1 No.2, September hlm. 84-97, online pada https://ojs.unm.ac.id/tomalebbi/article/v iew/1656/698

Sakdiyah, Halimatus dan Kustiawati Ningsih. 2013. "Mencegah pernikahan dini untuk membentuk generasi berkualitas (Preventing early-age marriage to establish qualified generation)", Masyarakat, Kebudayaan dan Politik, Vol. 26, No.1, hlm. 35-54, online pada http://journal.unair.ac.id/downloadfullpapers-mkp9b9d8e2432full.pdf

Sardi, Beteq. 2016. "Faktor-Faktor Pendorong Pernikahan Dini dan Dampaknya di Desa Mahak Baru Kecamatan Sungai Boh Kabupaten Malinau, eJournal Sosiatri-Sosiologi, Volume 4, Nomor 3, hlm 194-207, online pada http://ejournal.sos.fisipunmul.ac.id/site/wpcontent/uploads/2016/08/Jurnal\%20Onl ine\%20\%2808-29-16-07-11-46\%29.pdf
Siahaan, Nommy Horas Thombang. 2004. Hukum Lingkungan dan Ekologi Pembangunan. Jakarta:Erlangga.

Wisono Mulyadi, Anjar Sri Ciptorukmi Nugraheni. 2017. "Akibat Hukum Penetapan Dispensasi Perkawinan Anak di Bawah Umur (Studi Kasus di Pengadilan Agama Pacitan), Privat Law, Vol. V No. 2, Juli-Desember, hlm. 69-76.

\section{Peraturan Perundang-Undangan}

Undang-Undang Republik Indonesia Nomor 1 Tahun 1974 tentang Perkawinan.

Undang-Undang Republik Indonesia Nomor 39 Tahun 1999 tentang Hak Asasi Manusia.

Undang-Undang Republik Indonesia Nomor 35 Tahun 2014 tentang Perlindungan Anak 
